\title{
Check list of snakes from the Brejos de Altitude of Paraíba and Pernambuco, Brazil
}

\author{
Gentil Alves Pereira Filho ${ }^{1,3}$ \& Giovanna Gondim Montingelli ${ }^{2}$ \\ ${ }^{\text {I} P r o g r a m a ~ d e ~ P o ́ s-g r a d u a c ̧ a ̃ o ~ e m ~ C i e ̂ n c i a s ~ B i o l o ́ g i c a s ~(Z o o l o g i a), ~}$ \\ Laboratório/Coleção de Herpetologia, Departamento de Sistemática e Ecologia, \\ Universidade Federal da Paraíba - UFPB, Campus I, CEP 58059-900, João Pessoa, PB, Brasil \\ ${ }^{2}$ Museu de Zoologia da Universidade de São Paulo, Av. Nazaré, 481, \\ CEP 04263-000, Ipiranga, São Paulo, SP, Brazil \\ ${ }^{3}$ Corresponding author: Gentil Alves Pereira Filho, e-mail: gentilfilho@yahoo.com
}

PEREIRA FILHO, G.A. \& MONTINGELLI, G.G. Check list of snakes from the Brejos de Altitude of Paraíba and Pernambuco, Brazil. Biota Neotrop. 11(3): http://www.biotaneotropica.org.br/v11n3/en/ abstract?article+bn02211032011

\begin{abstract}
The Atlantic Forest is one of the priority areas for conservation in the world, since exhibits an overwhelming biodiversity of species. Among this biome stands the biogeographic unit located north of San Francisco River, which extends from the state of Alagoas to Rio Grande do Norte. On this portion of Atlantic Forest some isolated fragments of humid forests can be found, inserted in the arid Caatinga, known as Brejos de Altitude or Brejos Nordestinos. There is a total of 43 Brejos distributed in the states of Ceará, Rio Grande do Norte, Paraíba and Pernambuco and with the exception of some humid enclaves in the state of Ceará, the snake fauna of these areas are poorly known. Thus, our aim is to evaluate the current status of the snakes that inhabited these areas present on Paraíba and Pernambuco states, furnishing a preliminary list of the species housed on two representative collections concerning this region, Museu de Zoologia da Universidade de São Paulo (MZUSP) and Universidade Federal da Paraíba (UFPB). As a result, we recorded 27 species of snakes showing that this composition includes species primarily distributed in forest and open areas and also species widely distributed in different kind of biomes. We also stated that due to the present deforestation and the use of these areas for agricultural purposes the knowledge of its biodiversity is imperative, especially to generate information that will enable future management and conservation plans for these areas.
\end{abstract}

Keywords: serpentes, humid enclaves, northeastern, zoogeography, biodiversity.

PEREIRA FILHO, G.A. \& MONTINGELli, G.G. Check List das serpentes dos Brejos de Altitude da Paraíba e Pernambuco, Brasil. Biota Neotrop. 11(3): http://www.biotaneotropica.org.br/v11n3/pt/ abstract?article+bn02211032011

Resumo: A Floresta Atlântica é uma das principais prioridades para conservação no mundo apresentando uma alta riqueza e biodiversidade de espécies. Dentre as diversas feições deste bioma destaca-se a unidade biogeográfica localizada ao norte do Rio São Francisco, que se estende do Estado de Alagoas até Rio Grande do Norte. Nessa porção de Floresta Atlântica são encontrados fragmentos isolados de matas úmidas, inseridos meio a região árida da Caatinga, conhecidos como Brejos de Altitude ou Brejos Nordestinos. São 43 enclaves distribuídos nos estados do Ceará, Rio Grande do Norte, Paraíba e Pernambuco. Com exceção de alguns brejos situados no Ceará, a fauna de serpentes destes enclaves é pobremente conhecida, especialmente nos estados da Paraíba e Pernambuco. Desta forma, este trabalho teve por propósito avaliar o status atual do conhecimento das serpentes que habitam estas áreas de brejos nos estados da Paraíba e Pernambuco, fornecendo uma lista baseada em dados de duas coleções herpetológicas, Universidade Federal da Paraíba (UFPB) e Museu de Zoologia de Universidade de São Paulo (MZUSP). Como resultado, registramos 27 espécies de serpentes em 4 brejos da Paraíba e 4 de Pernambuco. A composição da fauna de alguns destes brejos consiste de espécies tanto de áreas florestais quanto de áreas abertas, assim como de espécies amplamente distribuídas em diversos tipos de ambientes. Constatamos também que devido à forte pressão antrópica que estes enclaves vêm sofrendo, estudos sobre biodiversidade destas áreas são imprescindíveis, visando gerar informações que viabilizem futuros planos de manejo e conservação dessas áreas. Palavras-chave: serpentes, matas serranas, região nordeste, zoogeografia, biodiversidade. 


\section{Introduction}

The Brazilian Atlantic Forest is one of the twenty-five priority areas for conservation in the world and exhibits high levels of species richness (Myers et al. 2000). One of these biogeographic units is located on the northern bank of São Francisco River, known as Northeastern Atlantic Forest; this area ranges from the State of Alagoas to the State of Rio Grande do Norte with some small fragments in the states of Ceará and Piauí (Tabarelli \& Santos 2004, Santos et al. 2007). This portion of Atlantic Forest is highly influenced by the Amazonian biota as well as by the Atlantic forest from southern and southeastern Brazil, which turns it into a very interesting biogeographic area (Rizzini 1963, Andrade-Lima 1982, Prance 1982, Tabarelli \& Santos 2004). Originally, the Northeastern Atlantic Forest covered a continuous area of approximately $6.4 \%$ of all the extension of the Brazilian Atlantic Forest (Tabarelli \& Santos 2004). However, due to its high potential for agricultural practices, this biome has been drastically reduced by anthropogenic activities (Vanzolini 1972, Theulen 2004). Nowadays, it covers only approximately 5,6\% of its original extension. Besides this core area, restricted to the coastal portion of northeastern Brazil, there are several humid forest remnants scattered throughout Caatinga lowlands, locally known as Brejos de Altitude or Brejos Nordestinos (Andrade-Lima 1960, Silva $\&$ Casteletti 2003, Tabarelli \& Santos 2004). These forest fragments are remnants of the cycles of expansion and retraction of the humid forests that were initiated during the Pleistocene and are represented by some "islands" of humid forest that cover some isolated plateaus and mountain ranges varying from 600 to $1200 \mathrm{~m}$ of altitude within the Caatinga lowlands (Bigarella et al. 1975, Andrade-Lima 1982, Lins 1989, Tabarelli \& Santos 2004). As a consequence of the high altitudes, orographic phenomena are commonplace: these areas show higher annual precipitation than the surrounding semiarid region, higher relative humidity (night and early morning mist) and, therefore, higher hydric availability to plants (Andrade-Lima 1966, Agra et al. 2004, Theulen 2004, Santos et al. 2007). These facts are responsible for the maintenance of evergreen and semideciduous forest in an area of such hydric shortage. Moreover, considering their floristic composition each of these areas has its own particularities (Agra et al. 2004) and some of them were assigned as priority areas for conservation (Porto et al. 2004).

Additionally, acting as refuges in the midst of arid region, these Brejos also present relatively more abundance and diversity of animal species and include some endemic and threatened species (Andrade \& Lins 1964, Borges-Nojosa \& Caramaschi 2003, Santiago et al. 2004, Theulen 2004). According to Tabarelli \& Santos (2004), 43 Brejos de altitude are known on the northeastern region, being 31 present in the states of Paraíba and Pernambuco. Considering its actual and reduced range in the states of Paraíba and Pernambuco $(8,1 \%$, nearly 950 $\mathrm{km}^{2}$ ) its conservation is crucial (Santos \& Tabarelli 2004, Tabarelli \& Santos 2004, Theulen 2004).

Among all known Brejos, those located in the state of Ceará were mostly studied due to their herpetofauna (Vanzolini 1981, Nascimento \& Lima-Verde 1989, Borges-Nojosa 1991, 2002, RebouçasSpieker 1981, Hoogmoed et al. 1994, Rodrigues \& Borges 1997, Borges-Nojosa \& Lima-Verde 1999, Borges-Nojosa \& Lima 2001, Borges-Nojosa \& Caramaschi 2003, Loebmann 2009, Loebmann \& Haddad 2010). As a result of these studies, some endemic species of amphibians (Adelophryne baturitensis and A. maranguapensis Hoogmoed et al. 1994), lizards (Mabuya arajara Rebouças-Spieker 1981, Colobosauroides cearensis Cunha, Lima-Verde \& Lima
1991, Leposoma baturitensis Rodrigues \& Borges 1997) and snakes (Atractus ronnie Passos et al. 2007) were recognized. Based on these findings, Borges-Nojosa \& Caramaschi (2003) stated that these enclaves act as refuges for the reminiscent fauna that have strict affinities to those major forested Neotropical biomes but also have considerable influence of typical elements of open areas.

Several Brejos, such as those located in Paraíba and Pernambuco, remain poorly known regarding their snake fauna and the vertebrate groups mostly studied were fishes (Rosa \& Groth 2004), mammals (Souza et al. 2004) and birds (Roda \& Carlos 2004). With the aim to explore the snake fauna of the enclaves of Paraíba and Pernambuco states we initiate this study providing the current knowledge of this group furnishing a checklist of the snakes housed in two herpetological collections. This checklist is the first approach concerning this snake fauna and thus must be considered as preliminary.

\section{Material and Methods}

All specimens and species analyzed during this study belong to two collections: Universidade Federal da Paraíba (UFPB) - the most regional and representative collection regarding the states of Paraíba and Pernambuco, and Museu de Zoologia da Universidade de São Paulo (MZUSP). There are no available specimens from brejos at the herpetological collection of the Universidade Federal de Pernambuco. The database of these collections was searched for all the localities associated with the "brejos" listed by Tabarelli \& Santos (2004). All the specimens collected are the result of scientific expeditions made in eight Brejos in the States of Ceará, Paraíba and Pernambuco and are housed in herpetological collections of Universidade Federal da Paraiba and Museu de Zoologia da Universidade de São Paulo. Specifically, data from the Herpetological Collection of Universidade Federal da Paraíba are the results of the project "Diversidade e Relações Biogeográficas da Herpetofauna e Pequenos Mamíferos em Brejos de Altitude do Nordeste Brasileiro" conducted by Dr. Alfredo Langguth.

Due to the lack of information about snakes of Brejos de altitude the material examined in these two collections is the main source of our list. All specimens had their identification confirmed by the authors using specialized literature (Peters \& Orejas-Miranda, 1986, Cunha \& Nascimento, 1978, Nascimento \& Lima-Verde, 1989). Taxonomic arrangement follows Tipton (2005), Zaher et al. (2009) and Hoser (2009), Tabarelli \& Santos (2004) included Agrestina, Pernambuco, as a Brejo de altitude, and we followed their assignment and included the material from this locality in the present study, but it is noteworthy that this Brejo also gathers, as stated by Rodrigues (2004), a snake fauna typical of the surrounding area. All the coordinates given follow Tabarelli \& Santos (2004) and Santos et al. (2007).

\section{Results}

The examination of 69 specimens (43 in UFPB and 26 in MZUSP) reveals a total of twenty seven species of snakes for eight Brejos de altitude in the states of Paraiba and Pernambuco, four Brejos in each state (Figures 1 and 2; Table 1), representing five families. The most diverse family was Dipsadidae, represented by 15 species, Colubridae by seven species, Viperidae by two species and both Boidae and Elapidae by only one species. We provide below a species list with information on the collector, voucher number and the Brejo where the specimens were collected. 
(a)

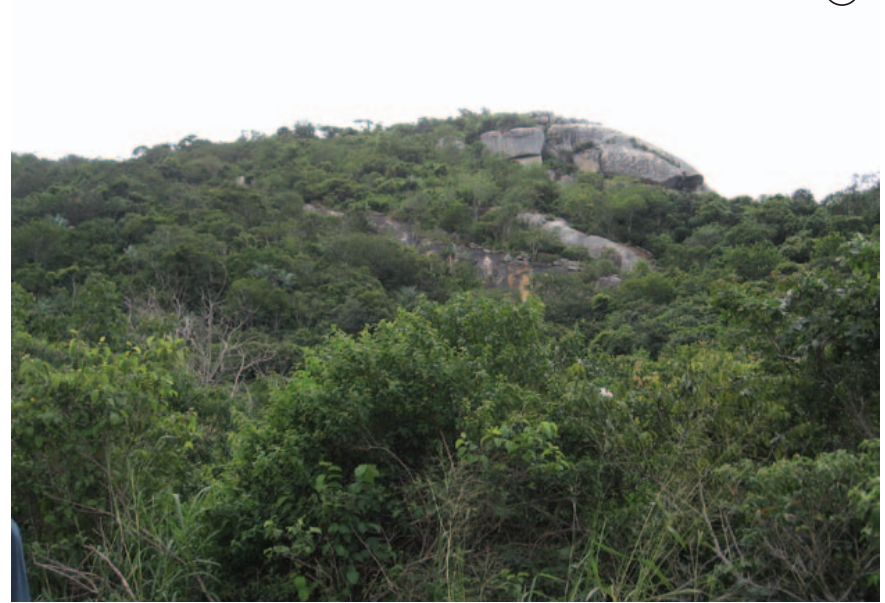

(C)

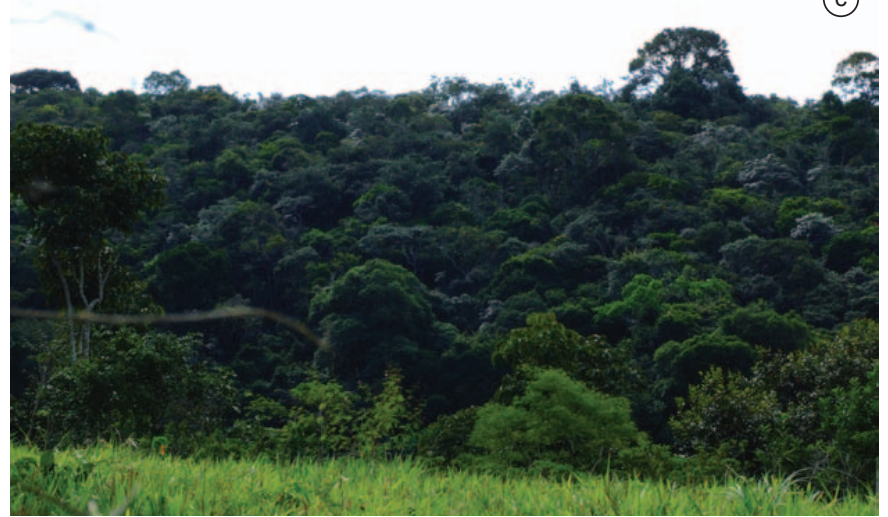

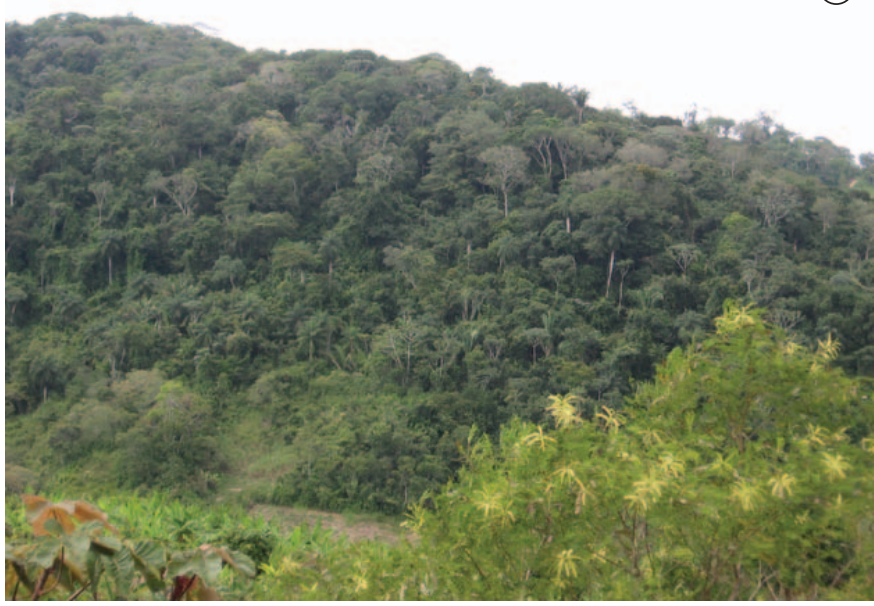

Figura 1. Imagens de alguns Brejos amostrados neste estudo. a) Brejo do Pico do Jabre, Maturéia, Paraíba; b) Brejo do Pau Ferro, Areia, Paraíba; c) Brejo de Goiamunduba, Bananeiras, Paraíba.

Figure 1. Pictures of some of the enclaves sampled in the present study. a) Brejo Pico do Jabre, Maturéia, Paraíba; b) Brejo do Pau Ferro, Areia, Paraíba; c) Brejo de Goiamunduba, Bananeiras, Paraíba.

\section{BOIDAE FAMILY}

Boa constrictor, Linnaeus, 1758: Pernambuco: Brejo Madre de Deus: Fazenda Rita: Mata do Bitury, 8-15.x.2002, collector: S. Abrantes (UFPB 3738).

\section{VIPERIDAE FAMILY}

Bothrops leucurus Wagler, 1824: Pernambuco: Brejo dos Cavalos: Caruaru: Parque Ecológico Municipal Professor João Vasconcelos Sobrinho, 31.viii.1997, collector: M. A. N. Souza (UFPB 2412); Fazenda Caruarú: 28.x.1997, collector: A. Langguth (UFPB 2712); Brejo Madre de Deus: Fazenda Rita: Mata do Bitury, 8-15.x.2002, collector: S. Abrantes (UFPB 3706, $3710,3711,3712)$.

Caudisona durissa (Linnaeus, 1758): Pernambuco: Brejo dos Bezerros: Bezerros: Fazenda Vertente: 12-22.iv.2002, collector: S. Abrantes (UFPB 3550, 3551).

\section{ELAPIDAE FAMILY}

Micrurus ibiboboca (Merrem, 1820): Paraíba: Brejo Pau Ferro: Areia, 7.ix.1983, collector: M. T. Rodrigues (UFPB 492), Paraíba: Brejo de Arara: Arara: 3.viii.1980, collector: C. Silva (UFPB 75).

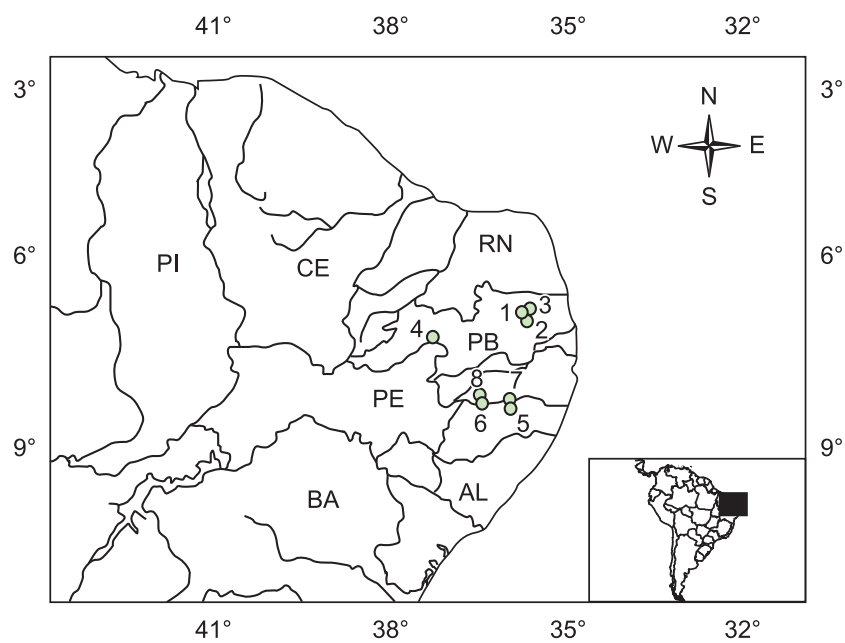

Figura 2. Mapa mostrando as localidades dos Brejos de Altitude amostrados neste estudo Paraíba: 1 = Arara; 2 = Areia; 3 = Bananeiras; 4 = Maturéia. Pernambuco: $5=$ Agrestina; $6=$ Bezerros; $7=$ Caruaru; $8=$ Madre de Deus.

Figure 2. Map showing the localities of the Brejos de Altitude sampled in this study. Paraíba: $1=$ Arara; 2 = Areia; 3 = Bananeiras; $4=$ Maturéia. Pernambuco: 5 = Agrestina; $6=$ Bezerros; $7=$ Caruaru; $8=$ Madre de Deus. 
Pereira Filho, G.A. \& Montingelli, G.G.

Table 1. List of the species recorded for each of the Brejo Nordestino sampled in the states of Paraíba and Pernambuco.

Tabela 1. Lista das espécies registradas para cada Brejo Nordestino amostrado nos estados da Paraíba e Pernambuco.

\begin{tabular}{|c|c|c|c|c|c|c|c|c|}
\hline \multirow[t]{2}{*}{ Species } & \multicolumn{3}{|c|}{ Paraíba } & \multicolumn{5}{|c|}{ Pernambuco } \\
\hline & Bananeiras & $\begin{array}{c}\begin{array}{c}\text { Brejo pau } \\
\text { ferro }\end{array} \\
\end{array}$ & $\begin{array}{c}\text { Brejo pico } \\
\text { do jabre }\end{array}$ & $\begin{array}{c}\text { Brejo de } \\
\text { agrestina }\end{array}$ & $\begin{array}{c}\text { Brejo de } \\
\text { arara }\end{array}$ & $\begin{array}{c}\text { Brejo dos } \\
\text { bezerros }\end{array}$ & $\begin{array}{c}\text { Brejo dos } \\
\text { cavalos }\end{array}$ & $\begin{array}{c}\text { Brejo madre } \\
\text { de Deus }\end{array}$ \\
\hline Boa constrictor & - & - & - & - & - & - & - & $\mathrm{x}$ \\
\hline Bothrops leucurus & - & - & - & - & - & - & $\mathrm{x}$ & $\mathrm{x}$ \\
\hline Caudisona durissa & - & - & - & - & - & $\mathrm{x}$ & - & - \\
\hline Chironius exoletus & - & $\mathrm{x}$ & - & $\mathrm{x}$ & - & - & $\mathrm{x}$ & - \\
\hline Drymarchon corais & - & - & - & $\mathrm{x}$ & - & - & - & - \\
\hline Drymoluber brazili & - & - & $\mathrm{x}$ & - & - & - & - & - \\
\hline Imantodes cenchoa & - & - & - & - & - & - & $\mathrm{x}$ & - \\
\hline Leptodeira annulata & - & - & - & - & - & - & $\mathrm{x}$ & - \\
\hline Leptophis ahaetulla & - & - & - & - & $\mathrm{x}$ & - & - & - \\
\hline Liophis miliaris & - & - & - & $\mathrm{x}$ & - & - & $\mathrm{x}$ & - \\
\hline Liophis poecilogyrus & - & $\mathrm{x}$ & $\mathrm{x}$ & $\mathrm{x}$ & - & - & - & - \\
\hline Liophis viridis & - & $\mathrm{x}$ & - & $\mathrm{x}$ & - & - & - & - \\
\hline Mastigodryas bifossatus & $\mathrm{x}$ & - & - & - & - & - & - & - \\
\hline Micrurus ibiboboca & - & $\mathrm{x}$ & - & - & - & - & - & - \\
\hline Oxybelis aeneus & - & $\mathrm{x}$ & - & - & - & - & - & - \\
\hline Oxyrhopus guibei & - & $\mathrm{x}$ & - & $\mathrm{x}$ & - & - & $\mathrm{x}$ & - \\
\hline Oxyrhopus trigeminus & - & - & - & - & - & $\mathrm{x}$ & - & - \\
\hline Philodryas nattereri & - & - & - & $\mathrm{x}$ & - & - & - & - \\
\hline Philodryas olfersii & - & - & $\mathrm{x}$ & $\mathrm{x}$ & - & - & - & - \\
\hline Pseudoboa nigra & - & - & - & $\mathrm{x}$ & - & - & - & - \\
\hline Sibynomorphus sp. & $\mathrm{x}$ & $\mathrm{x}$ & - & - & - & - & $\mathrm{x}$ & - \\
\hline Taeniophallus occipitalis & - & - & - & - & - & - & - & $\mathrm{x}$ \\
\hline Tantilla marcovani & - & - & $\mathrm{x}$ & - & - & - & - & - \\
\hline Tantilla melanocephala & - & $\mathrm{x}$ & - & - & - & - & - & $\mathrm{x}$ \\
\hline Thamnodynastes hypoconia & - & - & $\mathrm{x}$ & - & - & - & - & - \\
\hline Xenodon merremii & $\mathrm{x}$ & $\mathrm{x}$ & - & - & - & - & $\mathrm{x}$ & - \\
\hline Xenopholis undulatus & - & $\mathrm{x}$ & - & - & - & - & - & - \\
\hline
\end{tabular}

\section{COLUBRIDAE FAMILY}

Chironius exoletus (Linnaeus, 1758): Pernambuco: Brejo de Agrestina: Agrestina: iii.1974, collector: P. E. Vanzolini (MZUSP 4948); Brejo dos Cavalos: 13 km, ESE São Caetano, 1-5.x.1986, collector: M. T. Rodrigues (UFPB 2491); Paraíba: Brejo Pau Ferro: 6 km NW Areia, 8.iv.1983, collector: M. T. Rodrigues (MZUSP 8898).

Drymarchon corais (Boie, 1827): Pernambuco: Brejo de Agrestina: Agrestina: 27.iv.1972, collector: A. R. Hoge (MZUSP 4922, 4923, 4928, 4930); vi. 1974, collector: P. E. Vanzolini (MZUSP 4950, 4976).

Drymoluber brazili (Gomes, 1918): Paraíba: Brejo Pico do Jabre: Maturéia: 24.v.1978, collector: P. F. L. Duarte (MZUSP 7562).

Leptophis ahaetulla (Linnaeus, 1758): Paraíba: Brejo de Arara: Arara: Pedra da Glória: 3.viii.1980, collector: J. P. Santos (UFPB 77).

Mastigodryas bifossatus (Raddi, 1820): Paraíba: Bananeiras: 5.x.1985, collector: M. T. Rodrigues (MZUSP 8939).
Oxybelis aeneus (Wagler, 1824): Paraíba: Brejo Pau Ferro: 6 km NW Areia, 7.v-7.vi.1983, collector: M. T. Rodrigues (MZUSP 8954).

Tantilla marcovani Lema, 2004: PARAÍBA: Pico do Jabre: Maturéia, 15. ix. 2009 collector: G. A. P. Filho (UFPB 4886)

Tantilla melanocephala (Linnaeus, 1758): Pernambuco: Brejo Madre de Deus: Fazenda Rita: Mata do Bitury, 8-15.x.2002, collector: S. Abrantes (UFPB 3747); Paraíba: Brejo Pau Ferro: 6 km NW Areia, 7.v-7.vi.1983, collector: M. T. Rodrigues (MZUSP 8969).

\section{DIPSADIDAE FAMILY}

Dipsadinae Subfamily

Imantodes cenchoa (Linnaeus, 1758): Pernambuco: Brejo dos Cavalos: 13 km, ESE São Caetano, 3.x.1985, collector: M. T. Rodrigues (MZUSP 8897).

Leptodeira annulata (Linnaeus, 1758): Pernambuco: Brejo dos Cavalos: 13 km, ESE São Caetano, 2.x.1985, collector: M. T. Rodrigues (MZUSP 9016). 
Sibynomorphus sp: Pernambuco: Brejo dos Cavalos, 13.iii.1988, collector: R. Heyer (MZUSP 9606, 9607); Paraíba: Brejo Pau Ferro: 6 km NW Areia, 7.v-7.vi.1983, collector: M. T. Rodrigues (MZUSP 8900, 8901); Areia, 7.ix.1983, collector: M. T. Rodrigues (UFPB 494); Bananeiras: 8.x.1985, collector: M. T. Rodrigues (MZUSP 8904), 26.x.1985, collector: M. T. Rodrigues (MZUSP 8905).

\section{XENODONTINAE SUBFAMILY}

Liophis miliaris (Linnaeus, 1758): Pernambuco: Agrestina: Agrestina: iv.1972, collector: A. R. Hoge (MZUSP 4929, 495253); Brejo dos Cavalos: São Caetano, 1.x.1985, collector: M. T. Rodrigues (MZUSP 9017).

Liophis poecilogyrus (Wiedi, 1824): Pernambuco: Agrestina: Agrestina: vi.1974, collector: P. E. Vanzolini (MZUSP 4951, 4972); Paraíba: Brejo Pau Ferro: 6 km NW Areia, 7.v-7.vi.1983, collector: M. T. Rodrigues (MZUSP 8899); Areia, 7.ix.1983, collector: M. T. Rodrigues (UFPB 493); Brejo Pico do Jabre: Maturéia: 24.v.1978, collector: P. F. L. Duarte (MZUSP 7817).

Liophis viridis Gunther, 1862: Pernambuco: Agrestina: Agrestina: vi.1974, collector: P. E. Vanzolini (MZUSP 4925, 4942, 4946, 4965, 4970); Paraíba: Brejo Pau Ferro: Areia: 7.ix.1983, collector: M. T. Rodrigues (UFPB 490).

Oxyrhopus guibei Hoge e Romano, 1977: Pernambuco: Agrestina: Agrestina: iv.1972, collector: A. R. Hoge (MZUSP 4931); viii.1974, collector: P. E. Vanzolini (MZUSP 4954, 4955); Brejo dos Cavalos, 13 km, ESE São Caetano, 3.x.1985, collector: M. T. Rodrigues (MZUSP 9018); Paraíba: Brejo Pau Ferro: 6 km NW Areia, 7.v-7.vi.1983, collector: M. T. Rodrigues (MZUSP 8955); Areia, 7.ix.1983, collector: M. T. Rodrigues (UFPB 491).

Oxyrhopus trigeminus Duméril, Bibron \& Duméril, 1854: Pernambuco: Brejo dos Bezerros: Bezerros: Fazenda Vertente: 12-22.iv.2002, collector: S. Abrantes (UFPB 3547)

Philodryas nattereri Steindachner, 1870: Pernambuco: Agrestina: Agrestina: iii.1974, collector: P. E. Vanzolini (MZUSP 4973-75).

Philodryas olfersii (Lichtenstein, 1823): Pernambuco: Agrestina: Agrestina: iii.1974, collector: P. E. Vanzolini (MZUSP 4924, 4926-27, 4932-41, 4943-45, 4947, 4956-64, 4966-69, 4971); Paraíba: Brejo Pico do Jabre: Maturéia: 14.x.1984, collector: A. Langguth (UFPB 2725).

Pseudoboa nigra (Duméril, Bibron \& Duméril, 1854): Pernambuco: Agrestina: Agrestina: viii.1974, collector: P. E. Vanzolini (MZUSP 4949).

Taeniophallus occiptalis (Jan, 1863): Pernambuco: Brejo Madre de Deus: Fazenda Rita: Mata do Bitury, 8-15.x.2002, collector: S. Abrantes (UFPB 3713).

Thamnodynastes hypoconia (Cope, 1860): Paraíba : Pico do Jabre: Maturéia, 15. ix. 2009, collector: G. A. P. Filho (UFPB 4883)

Xenodon merremii (Wagler, 1824): Pernambuco: Brejo dos Cavalos: 13 km, ESE São Caetano, 1-5.x.1985, collector: M. T. Rodrigues (UFPB 2496), Paraíba: Brejo Pau Ferro: 6 km NW Areia, 7.v-7.vi.1983, collector: M. T. Rodrigues (MZUSP 8902-03), Areia: 10.vi.1983, collector: M. T. Rodrigues (MZUSP 8907), Bananeiras: 3.xii.1985, collector: M. T. Rodrigues (MZUSP 8940-42).

Dipsadidae incertae sedis (sensu Zaher et al., (2009))

Xenopholis undulatus (Jensen, 1900): Paraíba: Brejo Pau Ferro: Areia, 8.iv.1983, collector: M. T. Rodrigues (MZUSP 9100).

\section{Discussion}

The number of species obtained $(n=27)$ is certainly an underestimation, since no consistent sampling effort was performed on the 8 areas considered here, or in almost all other brejos. Moreover, the collecting localities studied here were only superficially sampled, without the use of standardized and specific methodologies for sampling snakes. Among these species, most of them are widely distributed in different biomes in Brazil, even open and forest areas such as Caatinga, Cerrado, Atlantic Coastal Forest and Amazonia.

Bothrops leucurus and Sybinomorphus sp. are forest dwellers while Oxyrhopus trigeminus and Xenodon merremii, are frequently found in open areas. Species currently distributed throughout the Caatinga may penetrate humid enclaves once they present more mesic conditions. An interesting example is Drymoluber brazili, a poorly known species distributed in the Cerrados of Central Brazil with records in Caatinga (Lehr et al. 2004). Our record of D. brazili in Pico do Jabre, Paraiba, is the first known for a forested environment. Imantodes cenchoa has occurrence in biomes such as Cerrado, although it is closely dependent of forest structure as well as Chironius exoletus. Despite the fact that the other species of our list are widely distributed elements or species closely related to open areas such as Caatinga, some of them (Liophis miliaris, Mastigodryas bifossatus, Pseudoboa nigra and Thamnodynastes hypoconia) were not previously recorded for any of the Brejos de Altitude in Paraiba and Pernambuco states. These new records are important since these Brejos constitute areas of contact among distinct biomes.

As we do not have precise information on the collecting habitat of the species recorded here, we were not able to provide further discussion on the species affiliation to the complex habitat gradient that are observed along the brejos. This is a problem observed in other species lists (Borges-Nojosa \& Caramaschi 2003, Loebmann \& Haddad 2010), so we emphasize the need of more detailed information associated to specimens, such as habitat type, altitude, climatic conditions, aside from the usual data recorded, as collecting locality and geographic coordinates. With this information, authors will be able to provide more adequate and complete species lists that will allow a more detailed knowledge on species assemblages through Neotropical region.

Concerning the taxonomy, some of the taxa recorded for these Brejos deserve special attention once they exhibit a confusing taxonomic status, such as Tantilla, Sibynomorphus, Micrurus and Thamnodynastes. The Sibynomorphus recorded here belongs to a new species (F. Franco, per. com.), apparently endemic of Brejos with only few specimens collected from brejos of Areia and Bananeiras in Paraiba state and Brejo of Serra dos Cavalos in Pernambuco state. The name Micrurus ibiboboca (Merrem, 1820) mentioned in our list has been used for two forms and one of them is a new coral snake. The specimens we analyzed belong to an undescribed species $(\mathrm{N}$. Jorge, per. com.). The name Tantilla melanocephala (Linnaeus, 1758) deserves attention, once the specimens analyzed show a strong variation in color and shape of helmet that does not correspond to the original description of the species. These examples show that the revisions of such genera must include samples of Brejos.

Borges-Nojosa (2007), in a long term study, recorded 33 species of snakes on Serra de Baturité, a brejo located in Central Ceará. This author suggests that this humid area harbor species from open and forested areas, species that are widely distributed in different biomes. The same pattern was postulated for the lizards and amphisbaenids from five humid enclave massifs in Ceará state (Araripe, Aratanha, Baturité, Ibiapaba and Maranguape) (Borges-Nojosa \& Caramaschi 2003), although each one of these enclaves seems to present its own particularities concerning their composition. 
However, the scarcity of representative lists on its composition does not allow deep comparisons of the taxocenoses of each Brejo. With this panorama it is impossible to know if all the enclaves share a similar snake fauna or not. Only the Brejos in Ceará state present lists of snakes that are results of long term inventories (Borges 1991, 2007) and thus, proper comparisons are possible only with these better known enclaves. Apparently, the typical Amazonian species found in Ceará enclaves such as Mastigodryas boddaerti (Sentzen, 1796), Lachesis muta (Linnaeus, 1766) and Sibon nebulata (Linnaeus, 1758) do not occur in the Paraiba and Pernambuco enclaves. Santos et al. (2007) stated that the Baturité enclave is more closely related to Amazon forest than to other enclaves in semi-arid region, due to the composition of vegetation. Perhaps, this similarity can also be explained due to geographical proximity and to a longer and more frequent connectivity between Amazon and the western Ceará enclaves. Molecular and phylogeographic studies may provide important data about the proximity of such herpetofaunas.

Finally, of all the 43 humid enclaves emphasized by Tabarelli $\&$ Santos (2004) only few were studied, principally in the state of Ceará (Borges-Nojosa 2002); the other 37 Brejos remain poorly known. This scenario demonstrates the necessity of studies in these areas, especially on those most critically reduced due to habitat fragmentation, hunting and deforestation. The knowledge of the fauna and flora in these enclaves must be done in order to provide information to create strategies of conservation and maintenance of such singular areas.

\section{Acknowledgements}

We are grateful to H. Zaher from the Museu de Zoologia da Universidade de São Paulo (MZUSP), G. Calazans from the Universidade Federal da Paraíba (UFPB) for the permission to examine the specimens under their care. We are indebted to Alfredo Langutth who kindly provided specimens under his care. We are also grateful to C. de Castro-Mello who provided technical support on MZUSP and to A. R. Percequillo who revised an earlier version of this manuscript.

\section{References}

AGRA, M.F., BARBOSA, M.R.V.\& STEVENS, W.D. 2004. Levantamento florístico preliminar do Pico do Jabre, Paraíba, Brasil. In Brejos de Altitude em Pernambuco e Paraíba, História Natural, Ecologia e Conservação (K.C. Porto, J.J.P. Cabral \& M. Tabarelli, eds.). Ministério do Meio Ambiente, Brasília, (série Biodiversidade, n. 9), p.123-137.

ANDRADE, G.O. \& LINS, R.C. 1964. Introdução ao Estudo dos "Brejos" Pernambucanos. Arq. Inst. Ci. Terra, Recife 2:21-33.

ANDRADE-LIMA, D. 1960. Estudos fitogeográficos de Pernambuco. Arq. Inst. Pesq. Agron. 5:305-341.

ANDRADE-LIMA, D. 1966. Esboço fitoecológico de alguns "brejos" de Pernambuco. Inst. Pesq. Agron. Nova Sér. Publ. Bot. Técn. Recife 8:3-27.

ANDRADE-LIMA, D. 1982. Present-day forest refuges In Northeastern Brazil. In Biological diversification In the tropics (G.T. Prance, ed.) Columbia University Press, New York, p.245-251.

BIGARELlA, J.J., ANDRADE-LIMA, D. \& RIEHS, P.J. 1975. Considerações a respeito das mudanças paleoambientais na distribuição de algumas espécies vegetais e animais no Brasil. Anais Acad. Bras. Ci. 47:411-464.

BORGES-NOJOSA, D.M. 1991. Herpetofauna do Maciço de Baturité, Estado do Ceará: composição, ecologia e considerações zoogeográficas. Dissertação de Mestrado, Departamento de Sistemática e Ecologia, Universidade Federal da Paraíba, João Pessoa.
BORGES-NOJOSA, D.M. 2002. Amphisbaenidae e Gymnophthalmidae dos Brejos-de-altitude do Estado do Ceará: composição, caracterização taxonômica e considerações biogeográficas (Squamata: Amphisbaenia, Sauria). Tese de Doutorado, Museu Nacional, Universidade Federal do Rio de Janeiro, Rio de Janeiro.

BORGES-NOJOSA, D.M. 2007. Diversidade de anfíbios e répteis da serra de Baturité, Ceará. In Diversidade e conservação da biota na serra de Baturité, Ceará (T.S. Oliveira \& F.S. Araújo, eds.). Universidade Federal do Ceará, Coelce, Fortaleza, p.225-247.

BORGES-NOJOSA, D.M. \& CARAMASCHI, U. 2003. Composição e análise comparativa da diversidade e das afinidades biogeográficas dos lagartos e anfisbenídeos (Squamata) dos Brejos Nordestinos. In Ecologia e Conservação da Caatinga (I.R. Leal, M. Tabarelli, J.M.Silva, eds.). Recife, p. 463-512.

BORGES-NOJOSA, D.M. \& LIMA, D.C. 2001. Dieta de Drymoluber dichrous (Peters, 1863) dos Brejos de altitude do Estado do Ceará, Brasil (Serpentes, Colubridae). Bol. Mus. Nac. R. Janeiro 468:1-5.

BORGES-NOJOSA, D.M. \& LIMA-VERDE, J.S. 1999. Geographic distribution: Lachesis muta rhombeata. Herpetol. Rev. 30:235.

CUNHA, O. R. \& NASCIMENTO, F. P. 1978. Ofídios da Amazônia. X - As cobras da região leste do Pará. Publ. Avul. Mus. Para. E. Goeldi 31:1-218.

HOOGMOED, M.S., BORGES, D.M. \& CASCON, P. 1994. Three new species of the genus Adelophryne (Amphibia: Anura: Leptodactylidae) from northeastern Brazil, with remarks on other species of the genus. Zool. Meded. 68:271-300.

HOSER, R. 2009. A reclassification of the Rattlesnakes; species formerly exclusively referred to the genera Crotalus and Sistrurus. Australas. J. Herpetol. 6:1-21.

LEHR, E., CARRILLO, N. \& HOOCKING, P. 2004. New species of Drymoluber (Reptilia: Squamata: Colubridae) from Southeastern Peru. Copeia 2004(1):46-52. http://dx.doi.org/10.1643/CI-02-248R1

LINS, R.C. 1989. As áreas de exceção do agreste de Pernambuco. Sudene, Recife, (Séries Estudos regionais, n. 20).

LOEBMANN, D. 2009. Xenopholis undulatus. Brazil: Ceará. Herpetol. Rev. 40:117.

LOEBMANN, D \& HADDAD, C.F.B. 2010. Amphibians and reptiles from a highly diverse area of the Caatinga domain: composition and conservation implications. Biota Neotrop. 10(3):227-257. http://dx.doi.org/10.1590/ S1676-06032010000300026

MYERS, N., MITTERMEIER, C.G., FONSECA, G.A.B. \& KENT, J. 2000. Biodiversity hotspots for conservation priorities. Nature 403:853-845. http://dx.doi.org/10.1038/35002501

NASCIMENTO, F.P. \& LIMA-VERDE, J.S. 1989. Ocorrência de ofídios de ambientes florestais em enclaves de matas úmidas do Ceará. (Ophidia: Colubridae). Bolm Mus. Para. E. Goeldi, Zool. 5(1):95-100.

PETERS, J. A. \& OREJAS-MIRANDA, B. 1986. Catalogue of the neotropical squamata, Part I. Snakes. Bull. U. S. Nat. Mus. 297:347p.

PRANCE, G.T. 1982. Forest refuges: evidences from woody angiosperms. In Biological diversification In the tropics (G.T. Prance, ed.) Columbia University Press, New York, p.137-158.

PORTO, K.C., GERMANO, S.R. \& BORGES, G.M. 2004. Avaliação dos brejos de altitude de Pernambuco e Paraíba, quanto à diversidade de espécies de Briófitas, para a conservação. In Brejos de Altitude em Pernambuco e Paraíba, História Natural, Ecologia e Conservação (K.C. Porto, J.J.P. Cabral \& M. Tabarelli, eds). Ministério do Meio Ambiente, Brasília (série Biodiversidade, n. 9), p.79-97.

REBOUÇAS-SPIEKER, R. 1981. Sobre uma nova espécie de Mabuya do Nordeste do Brasil (Sauria, Scincidae). Papéis Avuls Dept. Zool. 34:121-123.

RIZZINI, C.T. 1963. Nota prévia sobre a divisão fitogeográfica do Brasil. Revta Bras. Geogr. 24(1):1-64. 
RODA, S.A. \& CARLOS, C.J. 2004. Composição e sensitividade da Avifauna dos Brejos de Altitude do Estado de Pernambuco. In Brejos de Altitude em Pernambuco e Paraíba, História Natural, Ecologia e Conservação (K.C. Porto, J.J.P. Cabral \& M. Tabarelli, eds.). Ministério do Meio Ambiente, Brasília, (série Biodiversidade, n. 9), p.211-228.

RODRIGUES, M.T. 2004. Fauna de anfíbios e répteis das caatingas. In Biodiversidade da Caatinga: áreas e ações prioritárias para a conservação (J.M.C. Silva, M. Tabarelli, M.T. Fonseca, \& L.V. Lins, eds.). Ministério do Meio Ambiente, Brasília, p.173-179.

RODRIGUES, M.T. \& BORGES, D.M. 1997. A new species of Leposoma (Squamata: Gymnophthalmidae) from a relictual forest In semiarid Northeastern Brazil. Herpetologica 53:1-6.

ROSA, R.S. \& GROTH, F. 2004. Ictiofauna dos ecossistemas de Brejos de Altitude de Pernambuco e Paraíba. In Brejos de Altitude em Pernambuco e Paraíba, História Natural, Ecologia e Conservação (K.C. Porto, J.J.P. Cabral \& M. Tabarelli, eds.). Ministério do Meio Ambiente (série Biodiversidade, 9), Brasília, p.201-210.

SANTIAGO, A.C.P., BARROS, I.C.L. \& SYLVESTRE, L.S. 2004. Pteridófitas ocorrentes em três fragmentos florestais de um brejo de altitude (Bonito, Pernambuco, Brasil). Acta Bot. Brasilica 18(4):781-792. http://dx.doi.org/10.1590/S0102-33062004000400008

SANTOS, A.M.M., CAVALCANTI, D.R., SILVA, J.M.C. \& TABARELLI, M. 2007. Biogeographical relationships among tropical forests In northeastern Brazil. Journal of Biogeography 34:437-446. http://dx.doi. org/10.1111/j.1365-2699.2006.01604.x

SANTOS, A.M.M \& TABARELLI, M. 2004. Integridade, Esforço e Diretrizes para Conservação dos Brejos de Altitude da Paraíba e Pernambuco. In Brejos de Altitude em Pernambuco e Paraíba, História Natural, Ecologia e Conservação (K.C. Porto, J.J.P. Cabral \& M. Tabarelli, eds.). Ministério do Meio Ambiente, Brasília, (série Biodiversidade, n. 9), p.229-254.
SILVA, J.M.C \& CASTELETTI, C.H.M. 2003. Status of the biodiversity of the Atlantic Forest of Brazil. In The Atlantic Forest of South America: biodiversity status, threats, and outlook (C. Galindo-Leal \& I.G. Câmara, eds.). Center for Applied Biodiversity Science and Island Press, Washington, p.43-59.

SOUZA, M.A.N., LANGGUTH, A. \& GIMENEZ, E.A. 2004. Mamíferos dos Brejos de Altitude da Paraíba e Pernambuco. In Brejos de Altitude em Pernambuco e Paraíba, História Natural, Ecologia e Conservação (K.C. Porto, J.J.P. Cabral \& M. Tabarelli, eds.). Ministério do Meio Ambiente, Brasília, (série Biodiversidade, n. 9), p.229-254.

TABARELLI, M. \& SANTOS, A.M.M. 2004. Uma breve descrição sobre a história natural dos Brejos Nordestinos. In Brejos de Altitude em Pernambuco e Paraíba, História Natural, Ecologia e Conservação (K.C. Porto, J.J.P. Cabral \& M. Tabarelli, eds.). Ministério do Meio Ambiente, Brasília, (série Biodiversidade, n. 9), p.17-24.

THEULEN, V. 2004. Conservação dos Brejos de Altitude no Estado de Pernambuco. In Brejos de Altitude em Pernambuco e Paraíba, História Natural, Ecologia e Conservação (K.C. Porto, J.J.P. Cabral \& M. Tabarelli, eds.). Ministério do Meio Ambiente, Brasília, (série Biodiversidade, n. 9), p.299-302.

TIPTON, B.L. 2005. Snakes of the Americas: checklist and lexicon. Krieger Publishing Company, Malabar, Florida.

VANZOLINI, P.E. 1972. Miscellaneous notes In the ecology of some Brazilian lizards. Papéis Avuls Mus. Zool. 26(8):83-115.

VANZOLINI, P.E. 1981. A quasi-historical approach to the natural history of the differentiation of reptiles In tropical geographic isolates. Papéis Avuls Mus. Zool. 34(19):189-204.

ZAHER, H., GRAZZIOTIN, F.G., CADLE, J.E., MURPHY, R.W., MOURALEITE, J.C. \& BONATTO, S.L. 2009. Molecular phylogeny of advanced snakes (Serpentes: Caenophidia) with an emphasis on South American Xenodontines: A revised classification and descriptions of the new taxa. Papéis Avuls. Mus. Zool. 49(11):115-153. 